EGU2020-6950

https://doi.org/10.5194/egusphere-egu2020-6950

EGU General Assembly 2020

(c) Author(s) 2020. This work is distributed under

the Creative Commons Attribution 4.0 License.

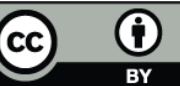

\title{
Investigations of the Oligocene-Miocene opening of the Ligurian Basin using refraction seismic data
}

Heidrun Kopp ${ }^{1}$, Anke Dannowski ${ }^{1}$, Ingo Grevemeyer ${ }^{1}$, Dietrich Lange ${ }^{1}$, Martin Thorwart ${ }^{2}$, Grazia Caielli ${ }^{3}$, Roberto Franco ${ }^{3}$, Florian Petersen ${ }^{1}$, Felix Noah Wolf ${ }^{1}$, and Bettina Schramm ${ }^{1}$

${ }^{1}$ GEOMAR, FB 4, Kiel, Germany

${ }^{2}$ Institut für Geowissenschaften, Universität Kiel, Germany

${ }^{3}$ IDPA-CNR, Istituto per la dinamica dei processi ambientali, Sezione di Milano, Milano, Italy

The Ligurian Basin is located north-west of Corsica at the transition from the western Alpine orogen to the Apennine system. The Back-arc basin was generated by the southeast trench retreat of the Apennines-Calabrian subduction zone. The opening took place from late Oligocene to Miocene. While the extension led to extreme continental thinning and un-roofing of mantle material little is known about the style of back-arc rifting.

To shed light on the present day crustal and lithospheric architecture of the Ligurian Basin, active seismic data have been recorded on short period ocean bottom seismometers in the framework of SPP2017 4D-MB, the German component of AlpArray. An amphibious refraction seismic profile was shot across the Ligurian Basin in an E-W direction from the Gulf of Lion to Corsica. The profile extends onshore Corsica to image the necking zone of continental thinning.

The majority of the refraction seismic data show mantle phases at offsets up to $70 \mathrm{~km}$. The arrivals of seismic phases were picked and inverted in a travel time tomography. The results show a crustmantle boundary in the central basin at $\sim 12 \mathrm{~km}$ depth below sea surface. The mantle shows rather high velocities $>7.8 \mathrm{~km} / \mathrm{s}$. The crust-mantle boundary deepens from $\sim 12 \mathrm{~km}$ to $\sim 18 \mathrm{~km}$ within 25 $30 \mathrm{~km}$ towards Corsica. The results do not map an axial valley as expected for oceanic spreading. However, an extremely thinned continental crust indicates a long lasting rifting process that possibly does not initiated oceanic spreading before the opening of the Ligurian Basin stopped. 